\title{
Public sector pay scales in PNG: are academics underpaid?
}

\author{
Thomas Wangi and Stephen Howes \\ Lecturer, Economics, UPNG and Director, Development Policy Centre, ANU
}

\begin{abstract}
PNG's public universities face difficulties in retaining academic staff, many of whom join government departments, statutory authorities, public enterprises, or the private sector for better paid jobs. We compare university pay in PNG with public service, statutory authority, and state-owned enterprise pay. We include allowances in our comparison, among them, importantly, the imputed value of university-provided housing. University salaries are uncompetitive for professors, and uncompetitive for all positions relative to the salaries offered by state-owned enterprises and probably some by statutory authorities. They are relatively competitive for positions below that of professor relative to the salaries offered by the public service. The PNG government will need to raise salaries to improve the competitive position of universities in those disciplines that are facing shortfalls. However, given that universities are likely to remain at a competitive disadvantage for some time to come, improving job satisfaction for academics and expanding the supply of quality candidates for areas where there are shortages will also be important.
\end{abstract}

\section{Introduction}

PNG's public universities face difficulties in retaining academic staff, many of whom join government departments, statutory authorities, public enterprises, or the private sector for better paid jobs. While this is not an unusual problem for a developing country, it seems to have got worse of late. It is possible that the booming resource sector has pushed up the salaries paid to skilled workers in the resources sector, and that this has had a flow-on effect on skilled workers in both the private and the public sectors. Universities might find it difficult to respond, and thus be left behind.

As far as we know, there has been no systematic effort to compare university and other public sector pay scales in PNG. No doubt such comparisons are made within government at the time when university salaries are set. However, such data is typically not made public.

There has been a recent cross-country study on academic salaries. Altbach, Resiberg, Yudkevich, Androushchak and Pacheco (2012) examine 28 countries. This provides a very useful benchmark which we use in our study.

Ideally, we would also like to include private sector pay scales in our comparison. However, due to data limitations we focus on the public sector, which we divide into four types: universities, government departments, statutory authorities and state-owned enterprises. Pay scales for government departments are centralized, but not for the other three types of institutions. For universities, statutory authorities, and state-owned enterprises we use data from individual institutions as examples. For universities, we use data for UPNG. We keep our statutory authority and state-owned enterprise examples anonymous to respect the confidential nature of their salary 
data. We are confident that our examples are broadly representative of the broader group from which they are drawn, and not unusually generous.

The next section sets out the pay scales for our four institutions. We then undertake a comparison, using three methods, each increasingly restrictive. The final section concludes and considers policy implications.

\section{Public Sector Pay Scale Review}

We include both base salary and allowances to calculate and compare gross salaries (before tax and employee superannuation contributions). We include the value of imputed rental assistance for academics. Some specific allowances are provided to some employees (e.g. for transport), and some also receive a Domestic Market Allowance, in recognition that the Base Salary alone is Employer superannuation contributions, annual leave fares and bonuses are excluded. The salaries we report are for national staff.

We lack data for the most senior positions, namely for heads of universities (Vice Chancellor), government departments (Secretary), statutory authorities (Chief Executive Officer), and public enterprise (Managing Director).

This section provides information on the pay scales for the four institutions we compare: UPNG, government departments, and our sample statutory authority and state-owned enterprise.

\subsection{UPNG (Academics)}

UPNG has 6 categories of academic staffs: Tutor, Lecturer 1, Lecturer 2, Senior Lecturer, Associate Professor, and Professor. Each category has 7 salary points, with 4 as the median base salary.

The Base Salary is the gross annual salary paid to each academic staff, and varies with staff classification and salary points. The Base Salary is subject to compulsory tax and superannuation deductions.

All staff also receives a number of allowances including the Domestic Market Allowance, Academic Teaching Allowance, and Gratuity (25\% of DMA and BS). The Heavy Duty Allowance is paid to Deans, Deputy Deans, Directors, and Division Heads. The allowances vary with staff classification and salary points and attract tax.

Housing is not provided to all UPNG academics. However, academics in the three senior classifications (Senior Lecturer, Associate Professor and Professor) are provided houses or flats upon contractual engagement. The lower three classifications are allocated houses when they are available. There is no housing allowance for academic staff, but rents are well below market levels. The difference between the market rental and the amount charged to staff times the probability of being provided with a house gives the Imputed Housing Value (IHV). Since this imputed value is not subject to tax, we also multiply it by the relevant marginal tax rate to make it comparable with other gross benefits. ${ }^{1}$ Table 1 shows the imputed housing values.

\footnotetext{
${ }^{1}$ We simply inflate imputed housing values by $30 \%$ to get a pre-tax equivalent. In fact, marginal tax rates rise to $40 \%$ for incomes in excess of $\mathrm{K} 70,000$ (see
} 
Table 1: UPNG Imputed Housing Value

\begin{tabular}{|l|l|l|l|l|l|}
\hline & $\begin{array}{l}\text { Share of } \\
\text { Staff with } \\
\text { House }\end{array}$ & $\begin{array}{l}\text { Market Rental } \\
\text { Value for House } \\
\text { Type per } \\
\text { Fortnight }\end{array}$ & $\begin{array}{l}\text { Rent Pay by } \\
\text { Staff per } \\
\text { Fortnight }\end{array}$ & $\begin{array}{l}\text { IHV per } \\
\text { Fortnight }\end{array}$ & Annual IHV \\
\hline & $\mathbf{( \% )}$ & $\mathbf{( K )}$ & (K) & (K) & (K) \\
\hline Tutor & 60 & 600 & 80 & 312 & 8,112 \\
\hline Lecturer 1 & 70 & 800 & 90 & 497 & 12,922 \\
\hline Lecturer 2 & 90 & 1,000 & 110 & 801 & 20,826 \\
\hline Senior Lecturer & 100 & 1,500 & 160 & 1,340 & 34,840 \\
\hline Associate Professor & 100 & 1,500 & 160 & 1,340 & 34,840 \\
\hline Professor & 100 & 1,500 & 160 & 1,340 & 34,840 \\
\hline
\end{tabular}

Notes: The three relevant variables are: share of staff allocated a house during the signing of the employment contract (S), the fortnightly rental value for a house type in the property market (Y), and rental amount paid by staff for a house or flat allocated by the university (Z). The Imputed Housing Value (IHV) is calculated as IHV = $S^{*}(Z-Y)$. Thus for tutors, IHV $=60 / 100^{*}(600-80)$ per fortnight $=K 312$ per fortnight $=K 312^{*} 26$ per year $=K 8,112$ per year

Sources: UPNG for housing allowances; authors' estimates for market values, and share of staff with a university-provided house.

Table 2 and Figure 1 show the academic staff salaries including the imputed housing value.

https://www.kpmg.com/global/en/issuesandinsights/articlespublications/taxation-internationalexecutives/papua-new-guinea/pages/income-tax.aspx) so this is a conservative conversion factor. 
Table 2: UPNG Academic Staff Salary Scale 2012

\begin{tabular}{|c|c|c|c|c|c|c|c|}
\hline \multirow[b]{2}{*}{ Grade } & \multirow[t]{2}{*}{ Base Salary } & \multicolumn{5}{|c|}{ Allowances } & \multirow[t]{2}{*}{$\begin{array}{l}\text { Total } \\
\text { Salary }\end{array}$} \\
\hline & & DMA & ATA & Gratuity & Housing & Total & \\
\hline & (K) & (K) & (K) & (K) & (K) & (K) & (K) \\
\hline UA1 (Tutor) & 25,158 & 7,000 & 6,432 & 8,040 & 10,546 & 32,017 & 57,175 \\
\hline UA2 (Lecturer I) & 29,632 & 11,500 & 8,226 & 10,283 & 16,799 & 46,808 & 76,440 \\
\hline UA3 (Lecturer II) & 35,386 & 14,000 & 9,877 & 12,347 & 27,074 & 63,298 & 98,684 \\
\hline UO4 (Senior Lecturer) & 42,818 & 19,700 & 12,504 & 15,630 & 45,292 & 93,125 & 135,943 \\
\hline UO5 (Associate Prof.) & 52,354 & 27,300 & 15,931 & 19,914 & 45,292 & 108,436 & 160,790 \\
\hline UO6 (Professor) & 64,595 & 37,200 & 20,359 & 25,449 & 45,292 & 128,300 & 192,895 \\
\hline
\end{tabular}

Notes: There are six grades for academic, and within each grade 7 points. We assess salaries at the median $4^{\text {th }}$ point. DMA is Domestic Market Allowance, ATA Academic Teaching Allowance, and IHV the Imputed Housing Allowance (Table 1).

Source: Human Resources Division, UPNG, and Table 1.

Figure 1: UPNG Academic Staff Salary Scale 2012

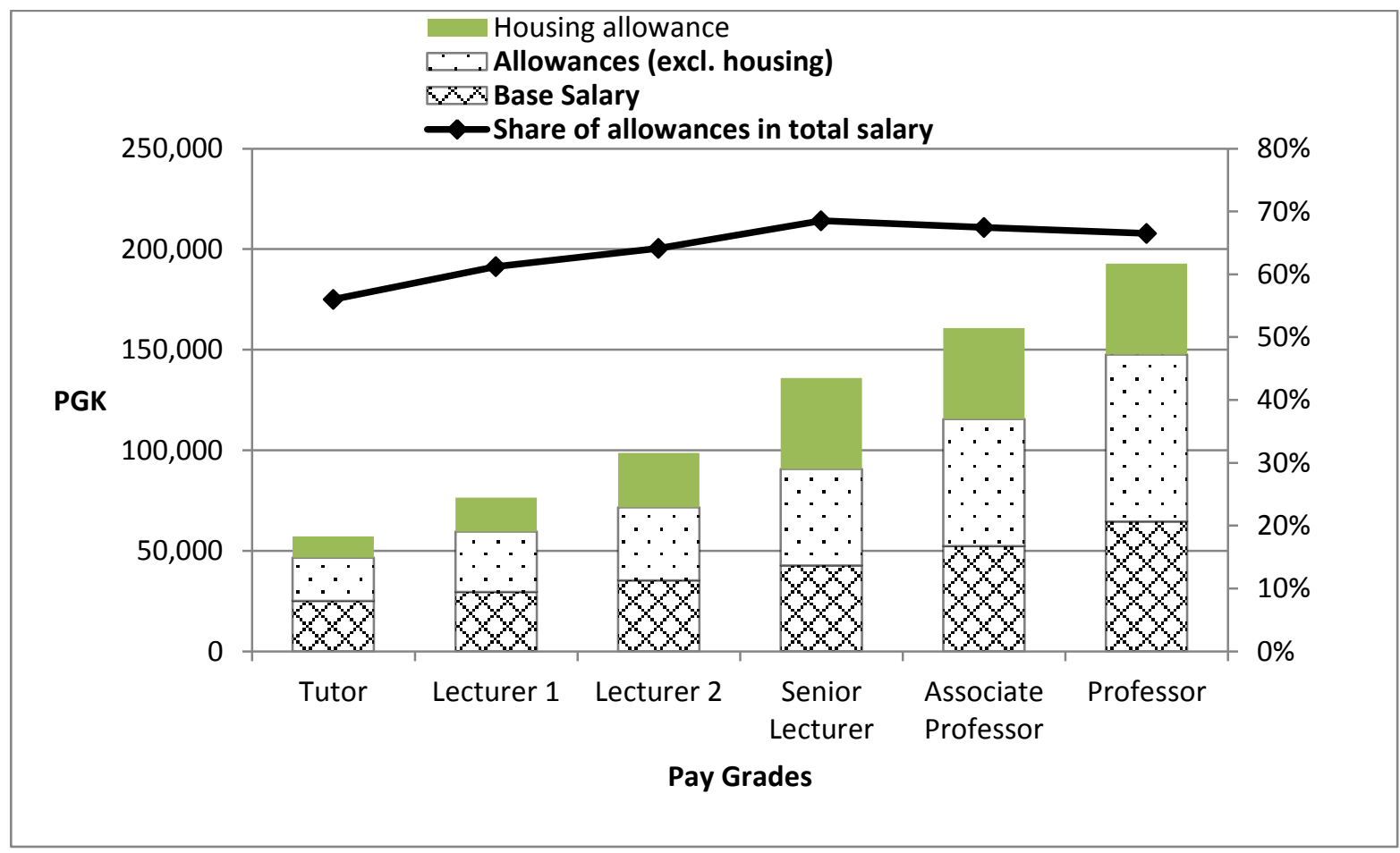

Source: Table 2.

As can been seen from Figure 1, for all positions the value of allowances is greater than the base salary. For example, in a year, a tutor can expect to receive $\mathrm{K57,175}$ of which 44 percent will be their base salary, a senior lecturer K135,943 (31 percent via their base salary) and a professor K192,895 (33 percent via their base salary). Housing allowances are significant, making, for example, 
a third of the total package a senior lecturer can expect. There are significant pay differentials, with a professor earning 2.5 times the salary of a lecturer.

\subsection{Public Service (Government Departments)}

The public service has 20 levels of pay grade up to Deputy Secretary. Each grade has 5 salary points, with 3 the median. The base salary varies with pay grades and salary points, and is subject to compulsory superannuation deduction and tax. ${ }^{2}$ Most senior officers receive Accommodation, Vehicles, Utilities, Telephone, and Entertainment Allowances. The Domestic Market Allowance is paid to both junior and senior staff above PS10. The standard housing allowance for grades below PS10 is K7 per fortnight.

Pay levels at median points for each of the 20 grades are shown in Table 3 and Figure 2.

Table 3: Public Service Salary Scale 2012

\begin{tabular}{|c|c|c|c|c|c|c|c|c|}
\hline & $\begin{array}{l}\text { Base } \\
\text { Salary }\end{array}$ & & & Allov & nces & & & $\begin{array}{c}\text { Total } \\
\text { Salary }\end{array}$ \\
\hline & & $\begin{array}{c}\text { Accomm- } \\
\text { odation }\end{array}$ & Vehicle & Utilities & $\begin{array}{c}\text { Tele- } \\
\text { phone }\end{array}$ & $\begin{array}{c}\text { Enter- } \\
\text { tainment }\end{array}$ & Total & \\
\hline & $(\mathrm{K})$ & $(\mathrm{K})$ & $(\mathrm{K})$ & $(\mathrm{K})$ & $(\mathrm{K})$ & $(\mathrm{K})$ & $(\mathrm{K})$ & $(\mathrm{K})$ \\
\hline PS01 & 8,290 & 0 & 0 & 0 & 0 & 0 & 0 & 8,290 \\
\hline PSO2 & 8,808 & 0 & 0 & 0 & 0 & 0 & 0 & 8,808 \\
\hline PSO3 & 9,724 & 0 & 0 & 0 & 0 & 0 & 0 & 9,724 \\
\hline PSO4 & 10,770 & 600 & 0 & 0 & 0 & 0 & 600 & 11,370 \\
\hline PS05 & 12,017 & 600 & 0 & 0 & 0 & 0 & 600 & 12,617 \\
\hline PS06 & 13,505 & 1,000 & 0 & 0 & 0 & 0 & 1,000 & 14,505 \\
\hline PS07 & 15,229 & 1,000 & 0 & 0 & 0 & 0 & 1,000 & 16,229 \\
\hline PS08 & 17,192 & 1,000 & 0 & 0 & 0 & 0 & 1,000 & 18,192 \\
\hline PSO9 & 19,551 & 1,500 & 0 & 0 & 0 & 0 & 1,500 & 21,051 \\
\hline PS10 & 22,282 & 1,500 & 0 & 0 & 0 & 0 & 1,500 & 23,782 \\
\hline PS11 & 25,489 & 1,500 & 0 & 0 & 0 & 0 & 1,500 & 26,989 \\
\hline PS12 & 28,657 & 2,250 & 0 & 0 & 0 & 0 & 2,250 & 30,907 \\
\hline PS13 & 31,044 & 2,500 & 0 & 0 & 0 & 0 & 2,500 & 33,544 \\
\hline PS14 & 33,785 & 2,500 & 0 & 0 & 0 & 0 & 2,500 & 36,285 \\
\hline PS15 & 37,290 & 5,000 & 0 & 350 & 0 & 0 & 5,350 & 42,640 \\
\hline PS16 & 41,413 & 5,000 & 0 & 350 & 0 & 0 & 5,350 & 46,763 \\
\hline PS17 & 49,732 & 7,500 & 0 & 1,200 & 900 & 1,800 & 11,400 & 61,132 \\
\hline PS18 & 58,727 & 15,000 & 15,000 & 1,800 & 1,200 & 2,600 & 35,600 & 94,327 \\
\hline PS19 & 71,977 & 15,000 & 15,000 & 1,800 & 1,200 & 2,600 & 35,600 & 107,577 \\
\hline PS20 & 87,937 & 26,000 & 26,000 & 2,600 & 1,800 & 3,600 & 60,000 & 147,937 \\
\hline
\end{tabular}

Notes: Table 3 shows base salary and allowances for each grade assessed at the median salary point within each grade.

Source: Public Relations Division, Department of Personnel Management.

\footnotetext{
${ }^{2}$ Tax deductions are exempted for pay grades PS03 to PS01 which are below the tax threshold of K10,000 per year.
} 
Figure 2: Public Service Salary Scale 2012

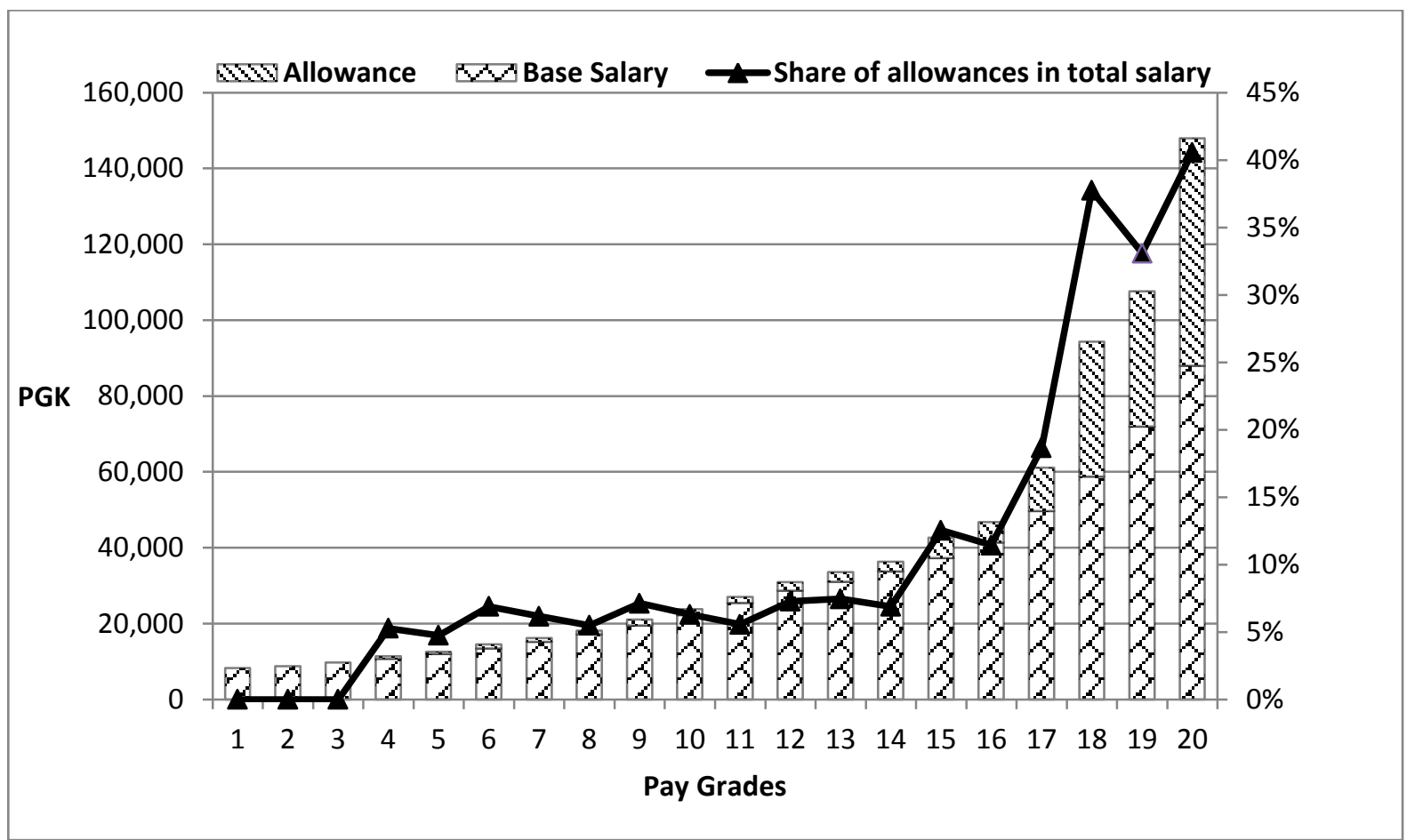

Source: Table 3

As can be seen from Figure 2, the public sector pay scale covers a wide spectrum, from less than $\mathrm{K} 8,300$ for the lowest grade (1) to K140,000 for the highest (20), with a ratio of 18 . The importance of allowances also varies. As Figure 2 shows, for grades 1 to 3 , there are no allowances; for grades 4 to 17 , allowances account between 5 and 19 percent of the total; and for the three very senior grades 18 to 20, allowances account at least 33 percent of the annual gross salary.

\subsection{Statutory authorities}

The statutory authority we examine has 16 levels of pay grade up to the General Manager, which is one below the head of the authority. Each grade has 7 salary points with 4 as the median salary base.The base salary varies with pay grades and salary points, and is subject to compulsory tax and superannuation deductions.

The allowances are the Domestic Market Allowance, Housing, Motor Vehicles, Entertainment, Utilities, Telephone and Gratuity. Each pay grade receives a housing allowance. Most other allowances are only paid to senior positions. Table 4 and Figure 3 show the results. 
Table 4: Statutory Authority Salary Scale 2013

\begin{tabular}{|c|c|c|c|c|c|c|c|c|c|c|}
\hline \multirow[b]{2}{*}{ Grade } & \multirow[t]{2}{*}{$\begin{array}{l}\text { Base } \\
\text { Salary }\end{array}$} & & \multicolumn{7}{|c|}{ Allowances } & \multirow[t]{2}{*}{$\begin{array}{l}\text { Total } \\
\text { salary }\end{array}$} \\
\hline & & SDMA & Housing & $\begin{array}{l}\text { Veh- } \\
\text { icle }\end{array}$ & $\begin{array}{c}\text { Enter- } \\
\text { tainment }\end{array}$ & $\begin{array}{l}\text { Utili- } \\
\text { ties }\end{array}$ & $\begin{array}{c}\text { Tele- } \\
\text { phone }\end{array}$ & $\begin{array}{l}\text { Grat- } \\
\text { uity }\end{array}$ & Total & \\
\hline & & (K) & $(\mathrm{K})$ & $(\mathrm{K})$ & $(\mathrm{K})$ & $(\mathrm{K})$ & $(\mathrm{K})$ & $(\mathrm{K})$ & (K) & (K) \\
\hline 1 & 13,165 & 0 & 2,000 & 0 & 0 & 0 & 0 & 0 & 2,000 & 15,165 \\
\hline 2 & 14,239 & 0 & 3,900 & 0 & 0 & 0 & 0 & 0 & 3,900 & 18,139 \\
\hline 3 & 15,581 & 0 & 3,900 & 0 & 0 & 0 & 0 & 0 & 3,900 & 19,481 \\
\hline 4 & 17,236 & 0 & 3,900 & 0 & 0 & 0 & 0 & 0 & 3,900 & 21,136 \\
\hline 5 & 19,248 & 0 & 3,900 & 0 & 0 & 0 & 0 & 0 & 3,900 & 23,148 \\
\hline 6 & 21,664 & 0 & 5,200 & 0 & 0 & 0 & 0 & 0 & 5,200 & 26,864 \\
\hline 7 & 24,661 & 0 & 5,200 & 0 & 0 & 0 & 0 & 0 & 5,200 & 29,861 \\
\hline 8 & 28,328 & 0 & 5,200 & 0 & 0 & 0 & 0 & 0 & 5,200 & 33,528 \\
\hline 9 & 32,801 & 7,000 & 10,400 & 0 & 0 & 0 & 0 & 0 & 17,400 & 50,201 \\
\hline 10 & 38,259 & 7,000 & 10,400 & 0 & 0 & 0 & 0 & 0 & 17,400 & 55,659 \\
\hline 11 & 44,924 & 15,000 & 15,000 & 10,000 & 0 & 0 & 0 & 11,231 & 51,231 & 96,155 \\
\hline 12 & 53,064 & 15,000 & 15,000 & 10,000 & 1,800 & 900 & 900 & 13,266 & 56,866 & 109,930 \\
\hline 13 & 63,084 & 15,000 & 15,000 & 12,000 & 1,800 & 900 & 900 & 15,771 & 61,371 & 124,455 \\
\hline 14 & 75,251 & 15,000 & 18,000 & 18,000 & 3,600 & 1,800 & 1,800 & 18,813 & 77,013 & 152,264 \\
\hline 15 & 78,784 & 15,000 & 18,000 & 18,000 & 3,600 & 1,800 & 1,800 & 19,696 & 77,896 & 156,680 \\
\hline 16 & 92,919 & 15,000 & 18,000 & 18,000 & 3,600 & 1,800 & 1,800 & 23,230 & 81,430 & 174,349 \\
\hline
\end{tabular}

Note: Table 4 shows median base salary and allowances for each grade. The data was sourced from the Human

Resources Division, Independent Consumer and Competition Commission.

Figure 3: Statutory Authority Salary Scale 2013

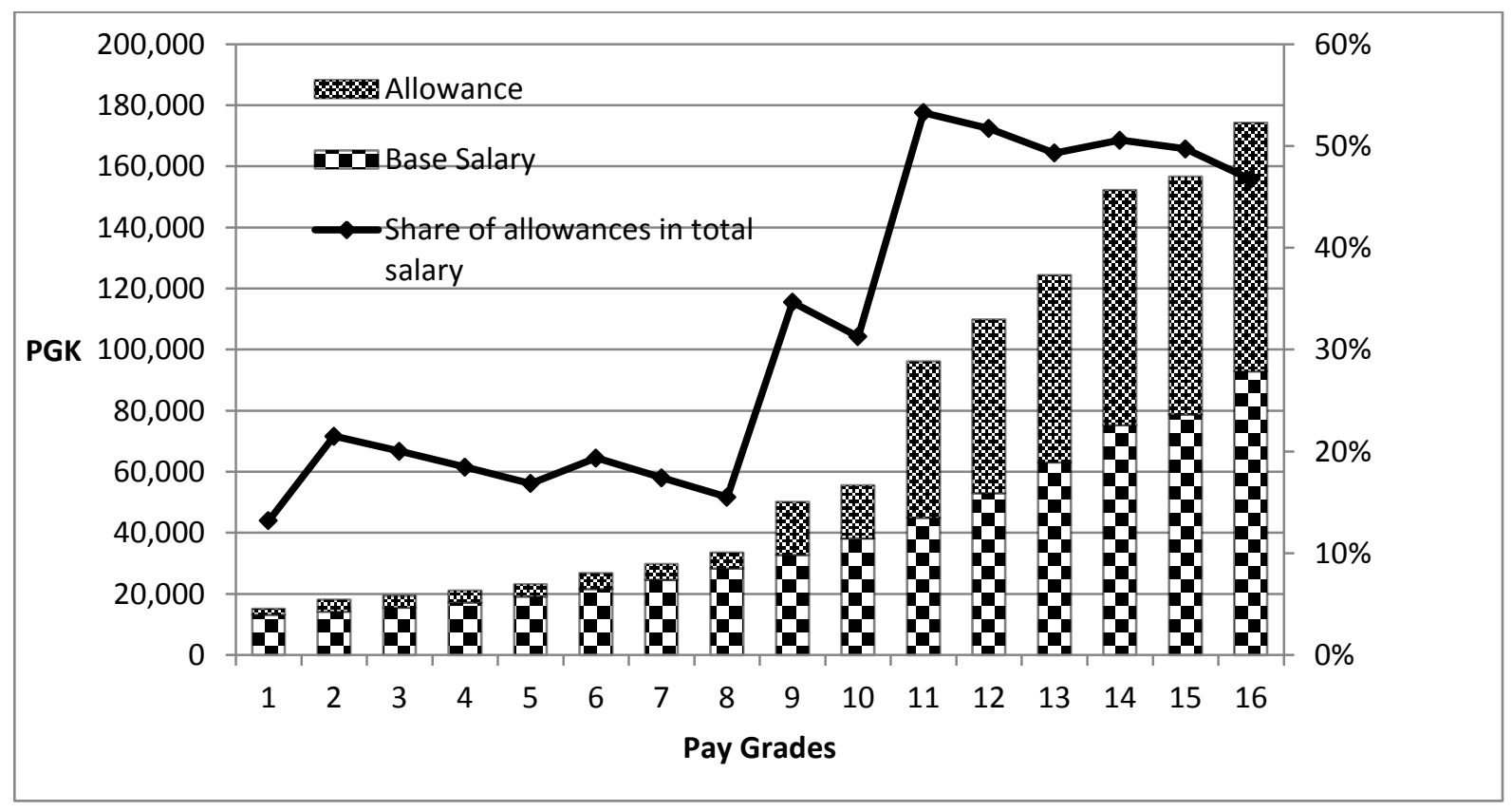

Source: Table 4 
Similarly to the public service, allowances are skewed to the top end. Senior positions receive significant allowances from K17,500 to K81,430 per year. As Figure 4 shows, for Grades 1 to 8 allowances account between 13 and 22 percent of the gross salary, and for Grades above 9 allowances account between 35 and 53 percent of the annual gross salary. The lowest grade (1) receives a total salary of $K 15,000$, while the highest grade (16) receives a total salary of $K 174,000$, giving a salary range of 11.5 .

\subsection{State Owned Enterprises}

The state-owned enterprise (SOE) we study has 12 levels of pay grade up to and including Chief Officer, which is a second-in-command position. Each grade has 9 salary points, 5 is the median. The base salary varies with pay grades and salary points, and is subject to compulsory tax and superannuation deductions. Individual allowances are for rent, vehicles, and a market allowance. We only have data on total allowances, not on different allowances separately. We also exclude any performance bonuses, and any incentive and retention payments. Table 5 and Figure 4 show the results.

Table 5: SOE Salary Scale 2012

\begin{tabular}{|l|r|r|r|}
\hline \multicolumn{1}{|c|}{ Grade } & \multicolumn{1}{|c|}{ Base Salary } & \multicolumn{1}{c|}{ Allowances } & \multicolumn{2}{c|}{ Total Salary } \\
\hline & (K) & (K) & 30,843 \\
\hline 2 & 19,801 & 11,042 & 41,124 \\
\hline 3 & 26,402 & 14,722 & 51,200 \\
\hline 4 & 32,521 & 18,679 & 63,978 \\
\hline 5 & 40,282 & 23,696 & 79,761 \\
\hline 6 & 49,983 & 29,778 & 100,393 \\
\hline 7 & 62,222 & 38,171 & 126,308 \\
\hline 8 & 77,594 & 48,714 & 158,766 \\
\hline 9 & 96,848 & 61,918 & 199,526 \\
\hline 10 & 121,026 & 78,500 & 250,602 \\
\hline 11 & 151,324 & 99,278 & 314,763 \\
\hline 12 & 189,383 & 125,380 & 352,535 \\
\hline
\end{tabular}

Notes: Table 4 shows median base salary and allowances for each grade. 
Figure 4: SOE Salary Scale 2012

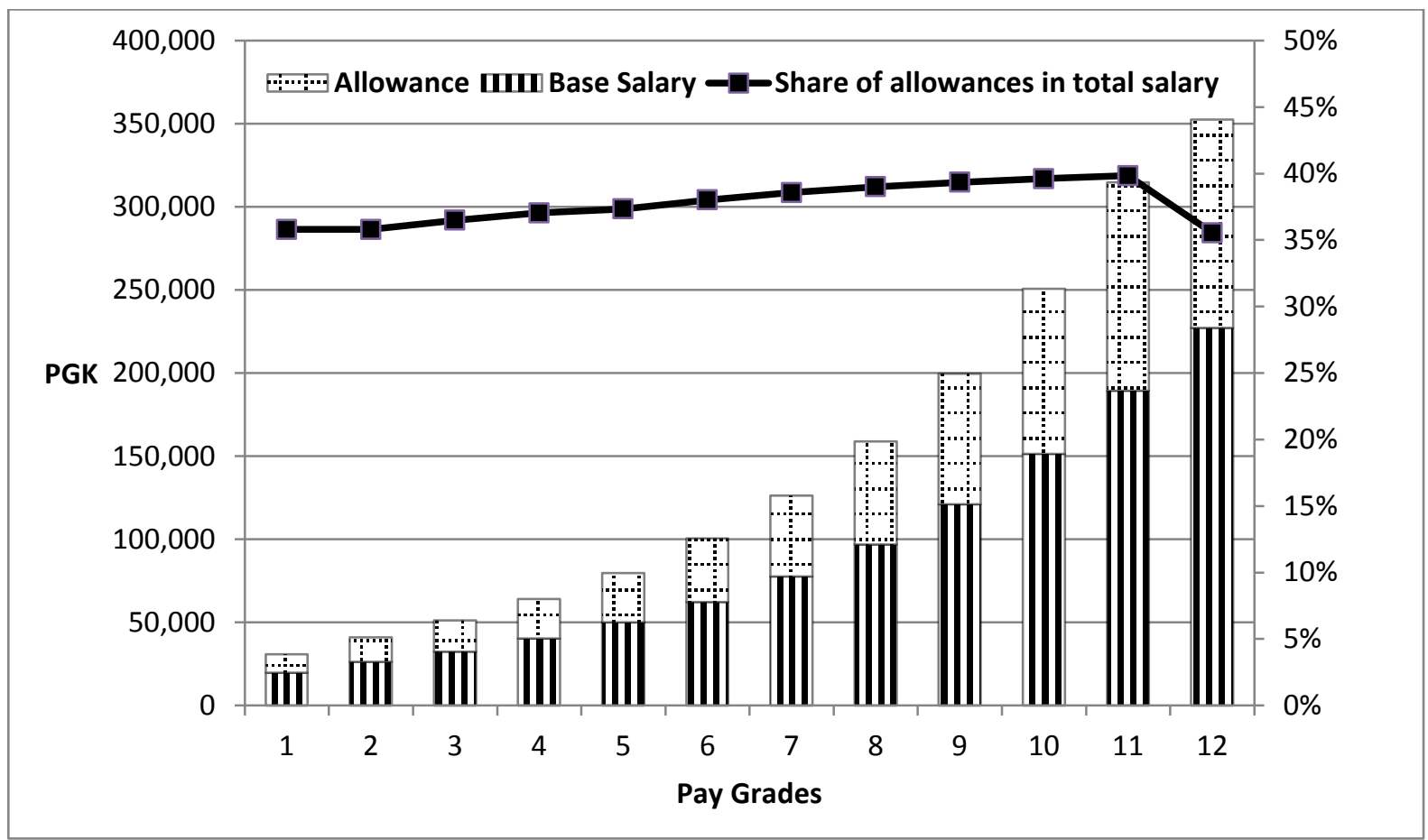

Source: Table 5

The share of allowances in the salary is very constant across grades at around 40 per cent. The lowest pay is K31,000 and the highest is $\mathrm{K} 353,000$, giving a ratio of 11 .

\subsection{Comparative analysis}

We provide three comparisons in this section. The first makes no assumptions concerning comparable grades, and simply looks at the full range of salaries on offer, as well as the varying importance of allowances. The second makes assumptions of which minimum and maximum scales are comparable across institutions (for the range of academic positions only), and then assumes that intermediate scales are spread evenly between these (Section 3.2). The third matches the full range of academic positions with comparable positions in other institutions (Section 3.3). Obviously, the fewer the assumptions made, the more reliance we can place on the results. A consistent pattern emerges from the three methods.

\subsection{Comparing salaries across different institutions}

We begin by comparing the four different distributions of pay scales without any assumptions at all about which positions are comparable with which.

Table 6 shows average salaries, and the share of base salaries and allowances for each of the four institution types. Average pay is highest for the SOE, then the Statutory Authority and UPNG, and then the public service. The average share of allowances in total pay is highest at UPNG and lowest in the public service. The pay range (ratio of highest to lowest pay) is the highest in the public sector, and lowest among academics. 
Table 6 Summary statistics for the four different pay scales

\begin{tabular}{|l|c|c|c|c|c|c|r|}
\hline & \multicolumn{4}{|c|}{ Averages } & Minimum & Maximum & Range \\
\hline & $\begin{array}{c}\text { Base } \\
\text { Salary }\end{array}$ & Allowances & Total & $\begin{array}{c}\text { Share of } \\
\text { Allowances in Total }\end{array}$ & & & \\
\hline & (K) & (K) & (K) & (\%) & (K) & (K) & Ratio \\
\hline UPNG & 41,657 & 71,345 & 113,002 & $63 \%$ & 54,741 & 182,443 & 3.3 \\
\hline PS & 30,171 & 8,463 & 38,633 & $22 \%$ & 8,290 & 147,937 & 17.8 \\
\hline SA & 39,576 & 29,613 & 69,188 & $43 \%$ & 15,165 & 174,349 & 11.5 \\
\hline SOE & 91,220 & 56,263 & 147,483 & $38 \%$ & 30,843 & 352,535 & 11.4 \\
\hline
\end{tabular}

Figure 5 shows the range of salaries at the different type of institutions. UPNG has the highest minimum pay. Maximum pay rates are similar for all three of UPNG, public service, and SA. Maximum pay is much higher at the SOE. Indeed, the top four grades of the SOE pay scale all exceed the maximum for the other three types.

Figure 5 The range of salaries across different public sector institutions

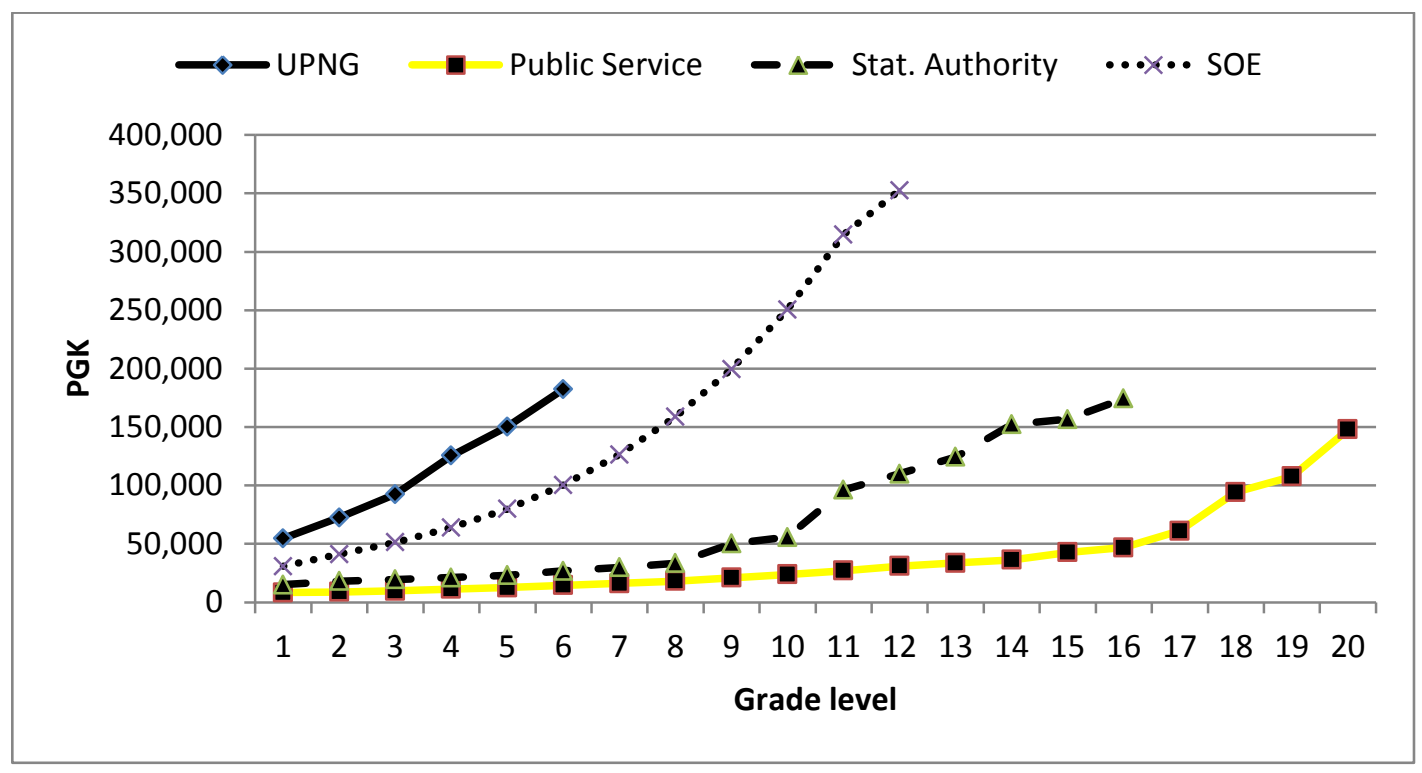


Figure 6 shows the share of allowances at the four types of institutions. Allowances are more important for every UPNG salary grade than they are for any other grade at any other institution. Allowances are only important for higher grades in the public service and SA, but are of roughly equal importance across grades for the SOE.

Figure 6 The share of allowances in total salaries across different public sector institutions

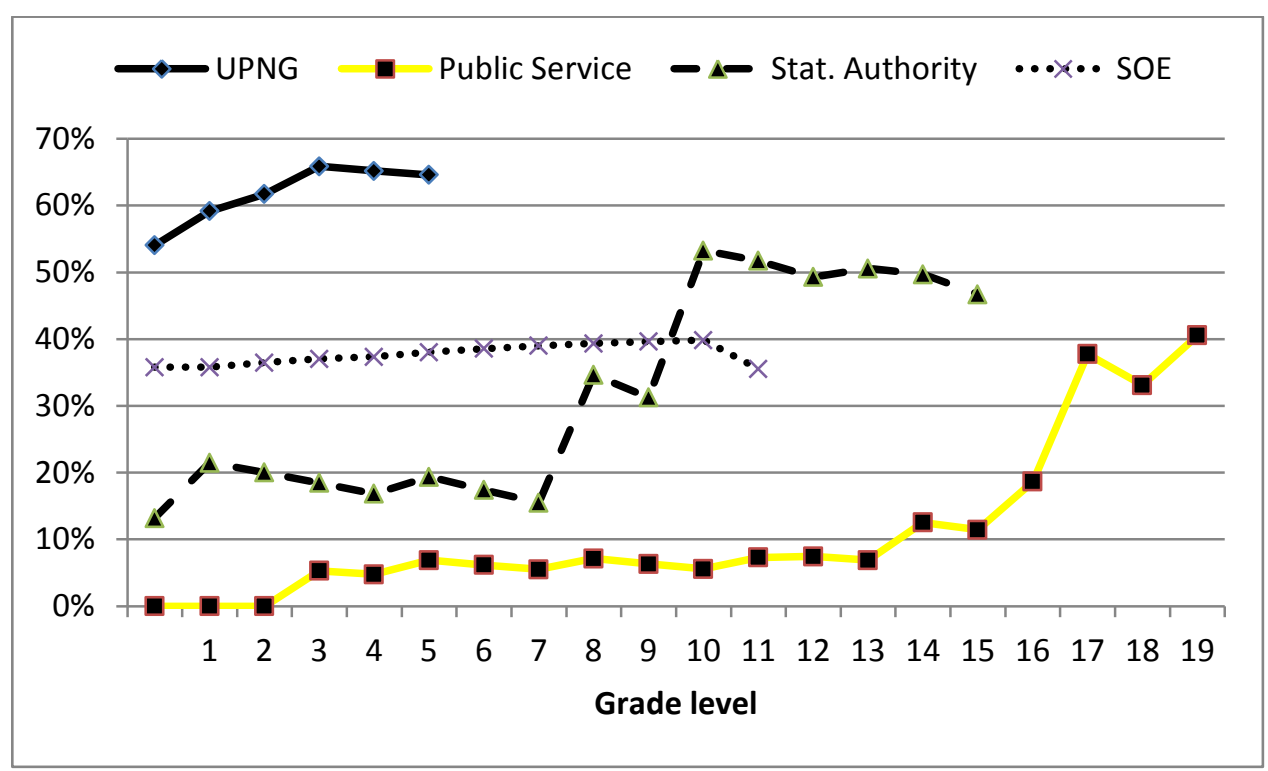

Finally, Figure 7 lines up all the pay grades together, from smallest to largest, with different institutions shown by different colours and different legends. We can see that the SOE grades cluster at the top and the public service grades at the bottom. University grades are largely in the top half, and SA grades are spread fairly evenly through the distribution, though not at either extreme.

Clearly is unlikely that universities can compete with SOEs. SOE salaries are much higher over a significant range of grades. The salary of a UPNG professor is similar to that of the most junior SOE manager. 


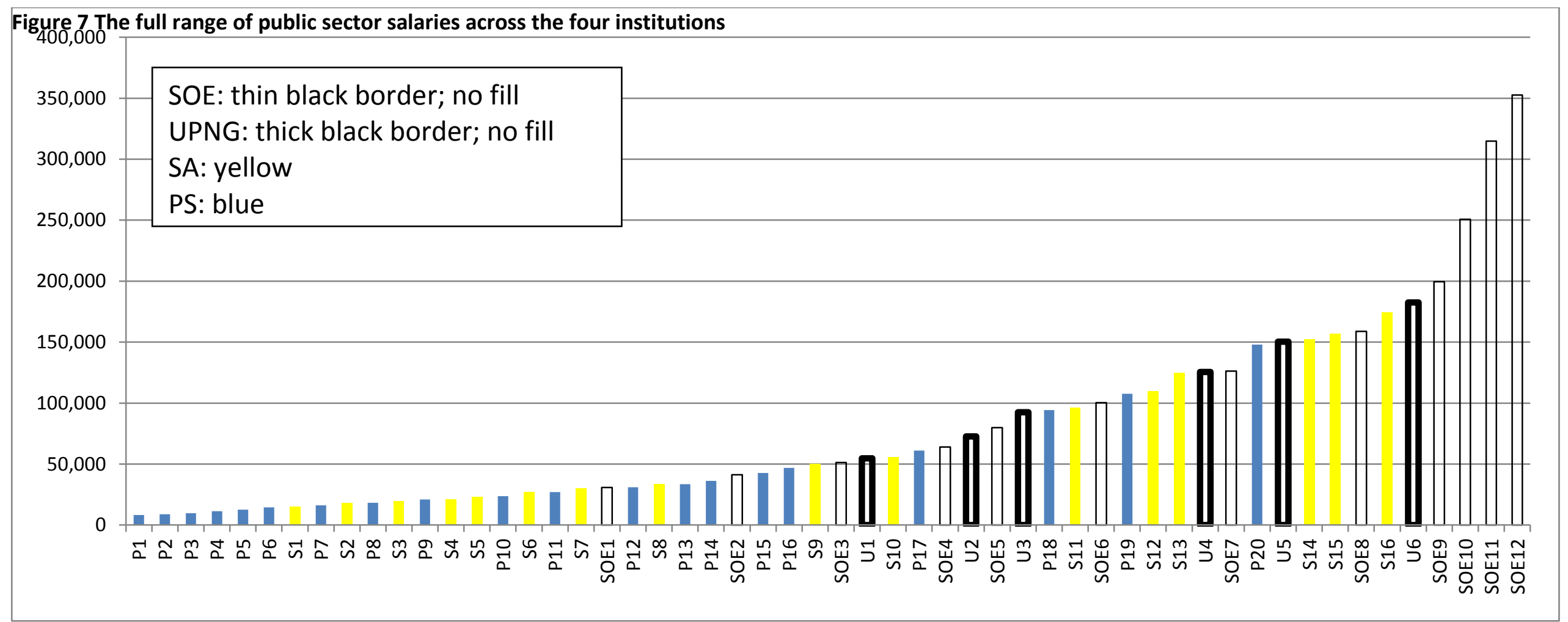




\subsection{Comparing salaries across different institutions for a comparable range}

To say more about the comparability of salaries we need to make some assumptions about the comparability of grades across institutions. To begin with, we make assumptions only about the comparability of the most junior and senior positions in common across the four data sets.

At the junior end, we assume that the role of a tutor (Grade 1 at the universities) is equivalent to that of a graduate at other organizations (Grade 9 at the public service and statutory authority, and Grade 6 at the SOE). This is a very reasonable assumption because the pool of university tutors is drawn from recent, if not immediate, graduates.

At the other end, the most senior academic role, that of a professor is comparable with Secretary of Government Departments, Chief Executive Officer of Statutory Authorities, and Managing Director of State Enterprises. (We know this because we can observe professors taking these roles.) We lack data for these comparator positions, and so the best comparison we can make at the senior end is to compare the role of an Associate Professor with Grade 20 (Deputy Secretary) in government departments, Grade 12 (General Manager) at ICCC, and Grade 12 (Chief Officer) at IBPC.

With these comparisons at both ends of the range, we then assume that intermediate grades are spread out evenly within each institution. Figure 8 shows the results. From this comparison we can see that, excluding the position of Professor, university academic salaries are competitive with the comparable statutory authority positions, and superior to those of the public service. However, academic salaries are only half to one third of comparable SOE positions.

Professorial positions are not at all competitive. This is because there is little difference between Associate Professor and Professor salaries. Yet the former are comparable with the highest positions in the public service and SAs for which we have data: the "2IC" (second-in-command) positions. And it is well known that there is a significant pay gap between between public service and SA $2 \mathrm{IC}$ and IIC (top) positions. 
Figure 8: Comparison of Salaries Across a Comparable Range

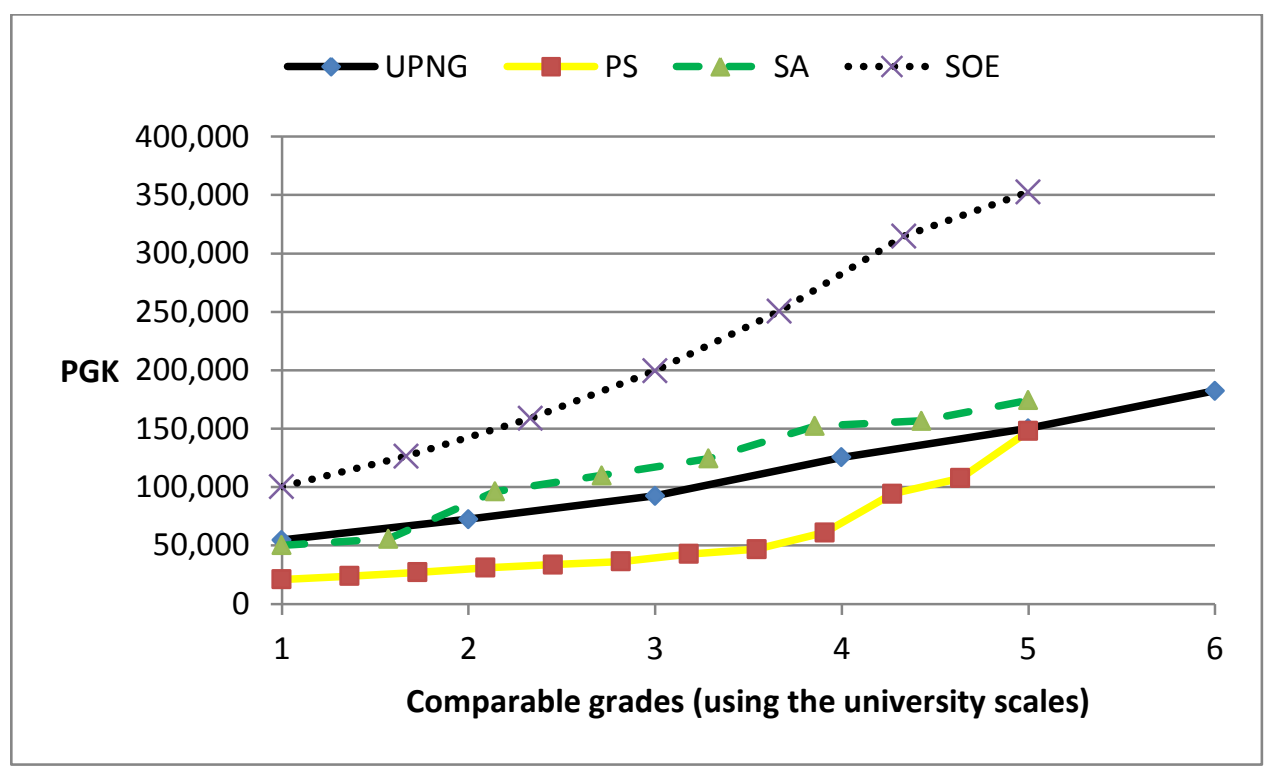

\subsection{Comparing salaries across different institutions for comparable positions}

Finally, we make the most detailed comparisons possible by identifying, based on our own judgement and feedback from others, comparable positions for the entire range of academic positions. See Table 8 for these assumptions, and Figure 9 and Table 9 for the results.

Table 8: Comparable Positions in the Public Sector

\begin{tabular}{|l|l|l|l|l|l|l|l|}
\hline \multicolumn{2}{|c|}{ UPNG } & \multicolumn{2}{c|}{ Government } & \multicolumn{2}{c|}{ SA } & \multicolumn{2}{c|}{ SOE } \\
\hline Grade & Designation & Grade & Designation & Grade & Designation & Grade & Designation \\
\hline 1 & Tutor & 9 & Graduate & 9 & Graduate & 6 & Graduate \\
\hline 2 & Lecturer 1 & 12 & Officer & 11 & Officer & 7 & Officer \\
\hline 3 & Lecturer 2 & 14 & Heads & 12 & $\begin{array}{l}\text { Senior } \\
\text { Officer }\end{array}$ & 8 & $\begin{array}{l}\text { Senior } \\
\text { Officer }\end{array}$ \\
\hline 4 & $\begin{array}{l}\text { Senior } \\
\text { Lecturer }\end{array}$ & 17 & $\begin{array}{l}\text { Assistant } \\
\text { Secretary }\end{array}$ & 14 & Manager & 10 & $\begin{array}{l}\text { Senior } \\
\text { Manager }\end{array}$ \\
\hline 5 & $\begin{array}{l}\text { Associate } \\
\text { Professor }\end{array}$ & 20 & $\begin{array}{l}\text { Deputy } \\
\text { Secretary }\end{array}$ & 16 & $\begin{array}{l}\text { General } \\
\text { Manager }\end{array}$ & 12 & $\begin{array}{l}\text { Chief } \\
\text { Officer }\end{array}$ \\
\hline 6 & Professor & & Secretary & & MD & & CEO \\
\hline
\end{tabular}


Figure 9: Base Salary and Allowances for Comparable Positions

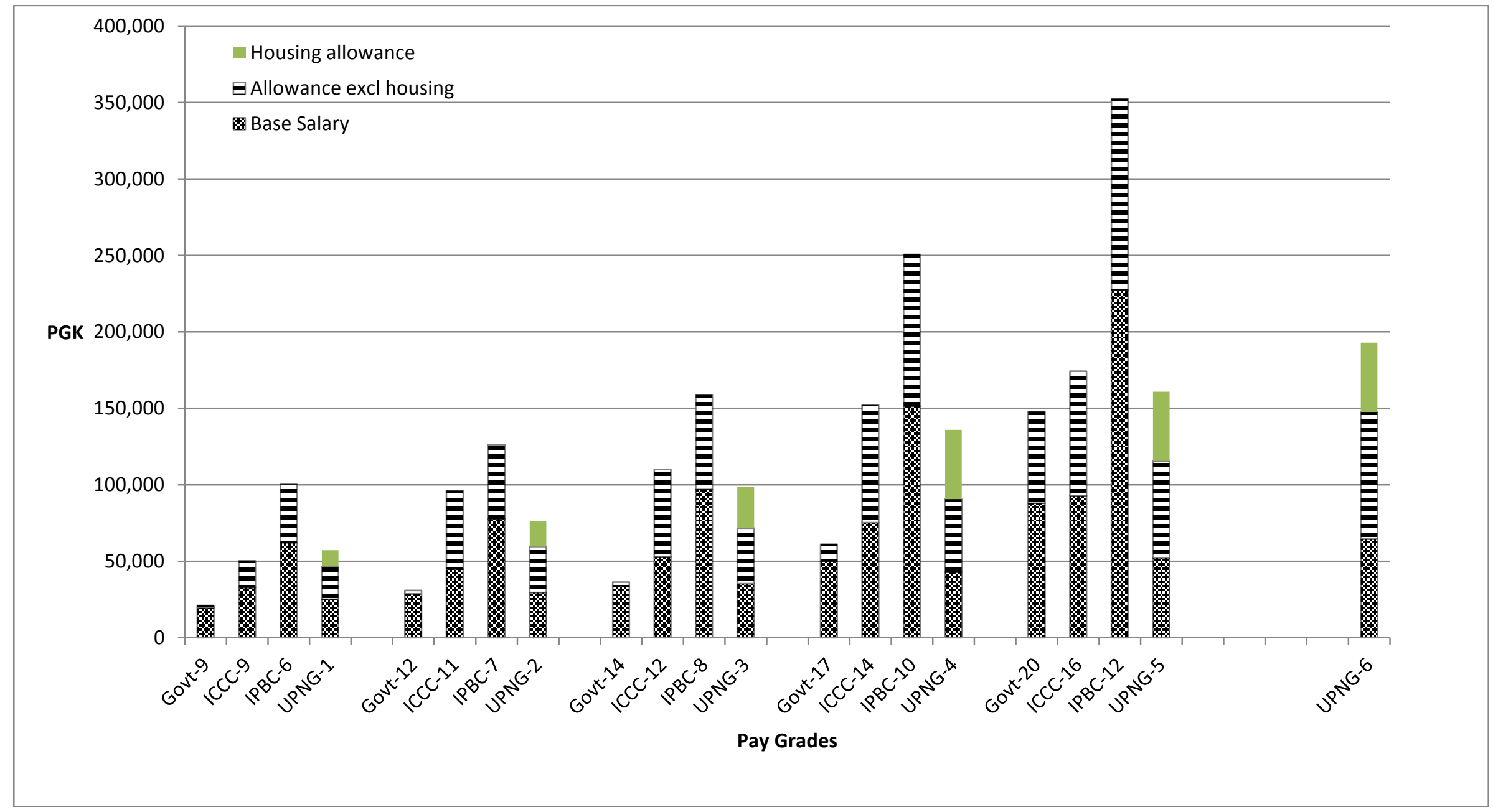


Table 9 Salary analysis for comparable positions

\begin{tabular}{|c|c|c|c|c|c|c|c|}
\hline \multicolumn{2}{|c|}{ UPNG } & \multicolumn{2}{|c|}{ Government } & \multicolumn{2}{|c|}{ SA } & \multicolumn{2}{|c|}{ SOE } \\
\hline Designation & $\begin{array}{c}\text { Salary } \\
\text { (K) }\end{array}$ & Designation & $\begin{array}{c}\text { Salary } \\
\text { (K) }\end{array}$ & Designation & Salary (K) & Designation & Salary (K) \\
\hline Tutor & 57,175 & Graduate & 21,051 & Graduate & 50,201 & Graduate & 100,393 \\
\hline Lecturer 1 & 76,440 & Officer & 30,907 & Officer & 96,155 & Officer & 126,308 \\
\hline Lecturer 2 & 98,684 & Heads & 36,285 & Senior Officer & 109,930 & $\begin{array}{l}\text { Senior } \\
\text { Officer }\end{array}$ & 158,766 \\
\hline Senior Lecturer & 135,943 & $\begin{array}{l}\text { Assistant } \\
\text { Secretary }\end{array}$ & 61,132 & Manager & 152,264 & $\begin{array}{l}\text { Senior } \\
\text { Manager }\end{array}$ & 250,602 \\
\hline $\begin{array}{l}\text { Associate } \\
\text { Professor }\end{array}$ & 160,790 & Deputy Secretary & 147,937 & $\begin{array}{l}\text { General } \\
\text { Manager }\end{array}$ & 174,349 & Chief Officer & 352,535 \\
\hline Professor & 192,895 & Secretary & & $\mathrm{MD}$ & & CEO & \\
\hline
\end{tabular}

For all positions, the SOE salaries are by far the highest, and 60 to 120 per cent above the comparable academic positions. For four out of the five positions, the SA positions are the second highest. However, the differences between the SA and academic positions are not large, often only around $10 \%$. All comparable UPNG positions offer higher salaries than the comparable government positions. The differences are large (more than double) until the Associate Professor level.

\section{International comparisons}

Using the work of Altbach et al. (2012) mentioned earlier, we can supplement the above analysis of salaries across the public sector in PNG with a comparison of academic salaries in PNG and 28 other countries. Altbech et al. contain three types of comparisons. The first is in US dollars, using purchasing power parities, for both "top" and "entry-level" positions. (They also include a comparison for average salaries but it is not clear how this is calculated.) PNG is added to the crosscountry comparisons in Figure 9. (We deflate salaries to 2005 prices using the CPI (deflator of approximately 1.5) and then convert to USD using a PPP XR of 1.7 from WorldDatabank for 2005, suing the PPP exchange rate for consumption.) PNG academic salaries emerge fairly well from this comparison, coming in at around the half-way mark, not far below Australia. Among developing countries, the only ones with higher professorial (top) salaries than PNG are Malaysia, South Africa and India. The other 12 developing countries in the sample all have professorial salaries below PNG. 


\section{Figure 10 PNG academic salaries in international comparison}

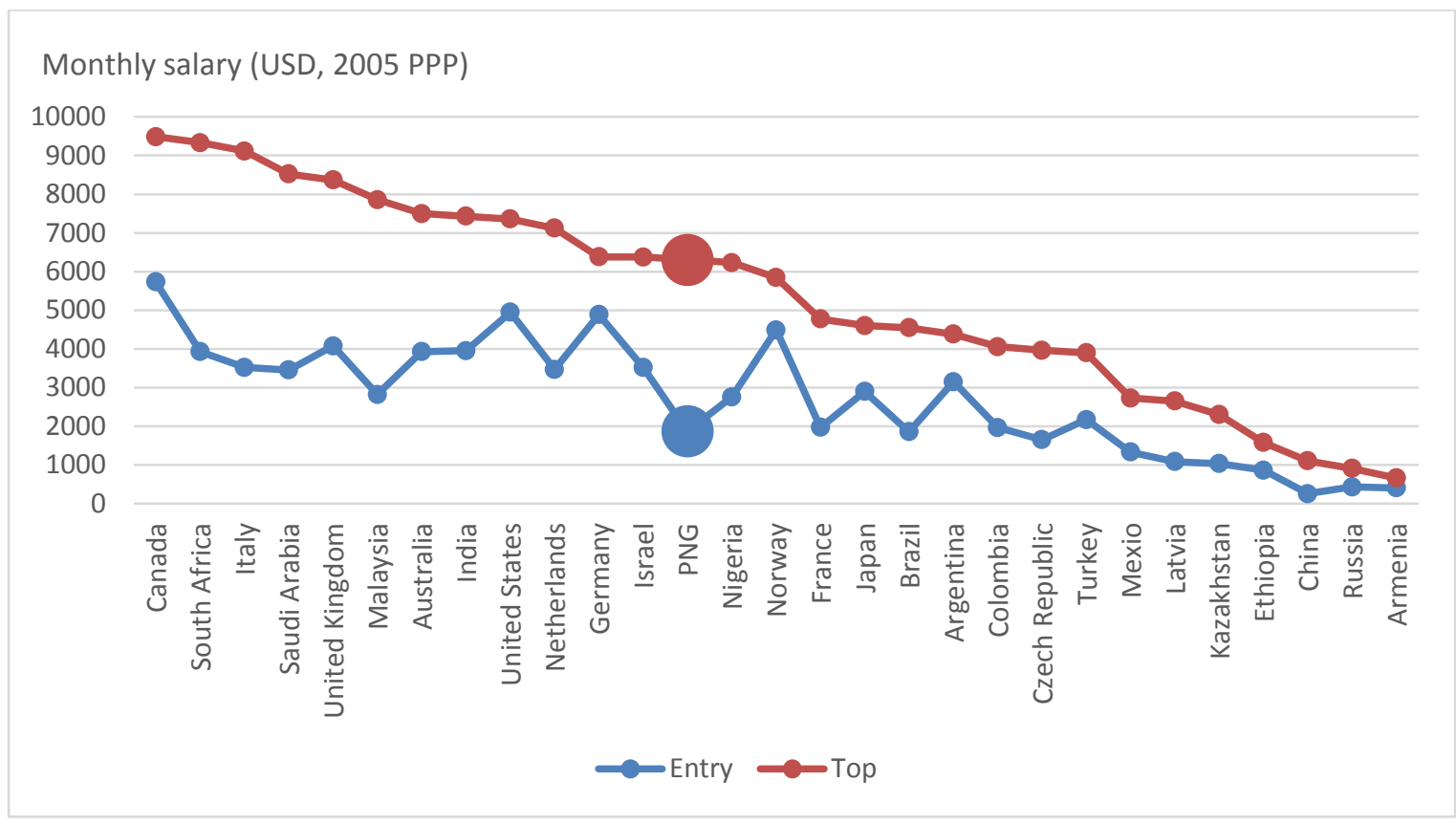

Sources: PNG data from this paper. Other countries from Altbach et al. (2012).

Since academic salaries are internationally comparable in PNG, but PNG remains a very poor country, this must mean that the ratio of salaries to GDP per capita in PNG must be high. Figure 11 confirms that indeed, this ratio is higher for PNG than for any of the 28 countries surveyed by Altbach et al., and by a considerable margin. The ratio in PNG is 35 . The next highest are Nigeria, India and Ethiopia, all around 25.

Figure 11 Professorial salaries relative to GDP per capita in PNG and other countries.

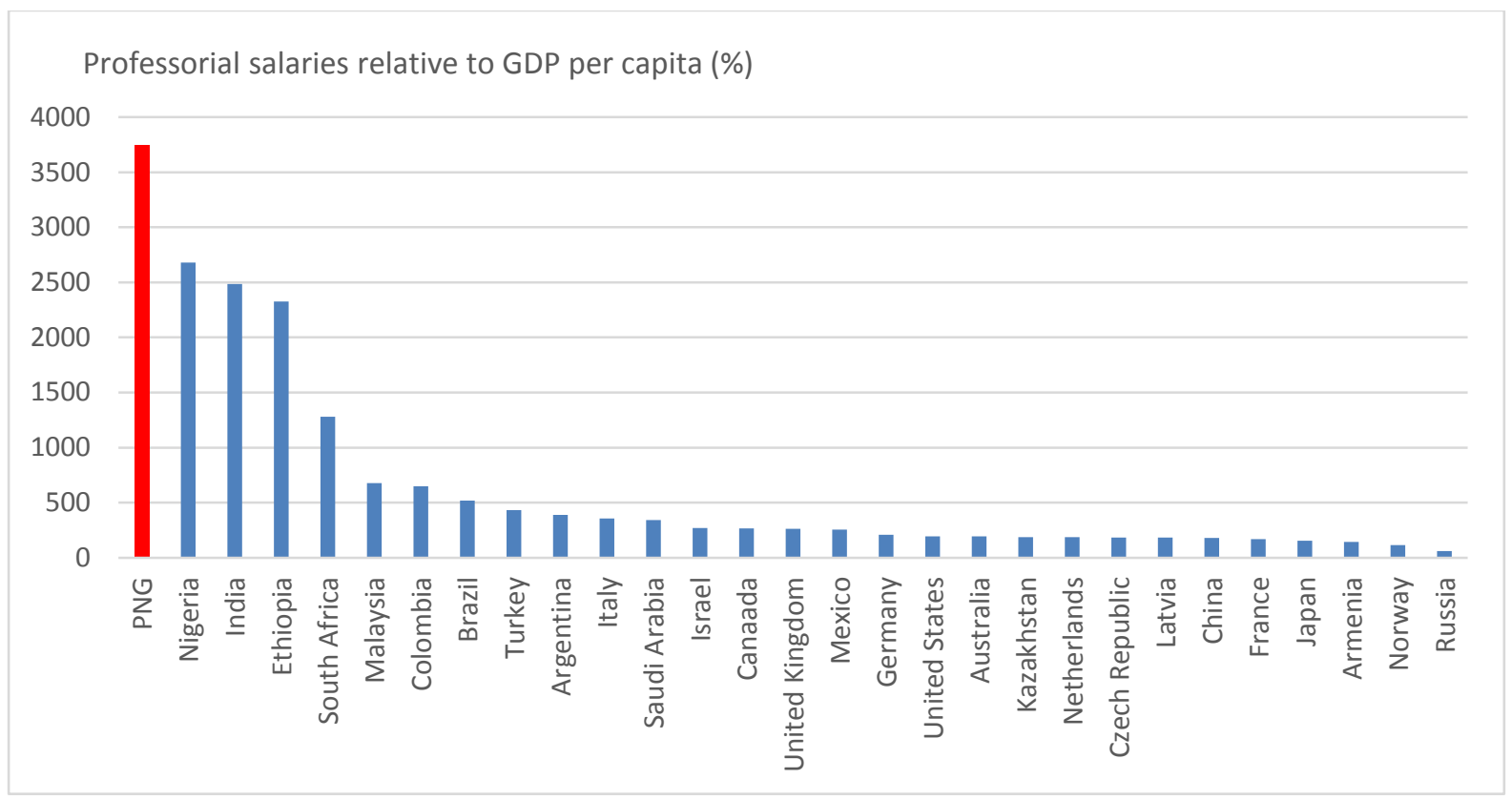

Sources: PNG data from this paper. Other countries from Altbach et al. (2012). 
The final comparison involves the relativity of professorial to junior academic pay. PNG has a relatively large differential between professorial and tutor pay, second only to China among the countries which Altbach et al. examine

Figure 12 The ratio of professorial to entry-level academic salaries in PNG and other countries.

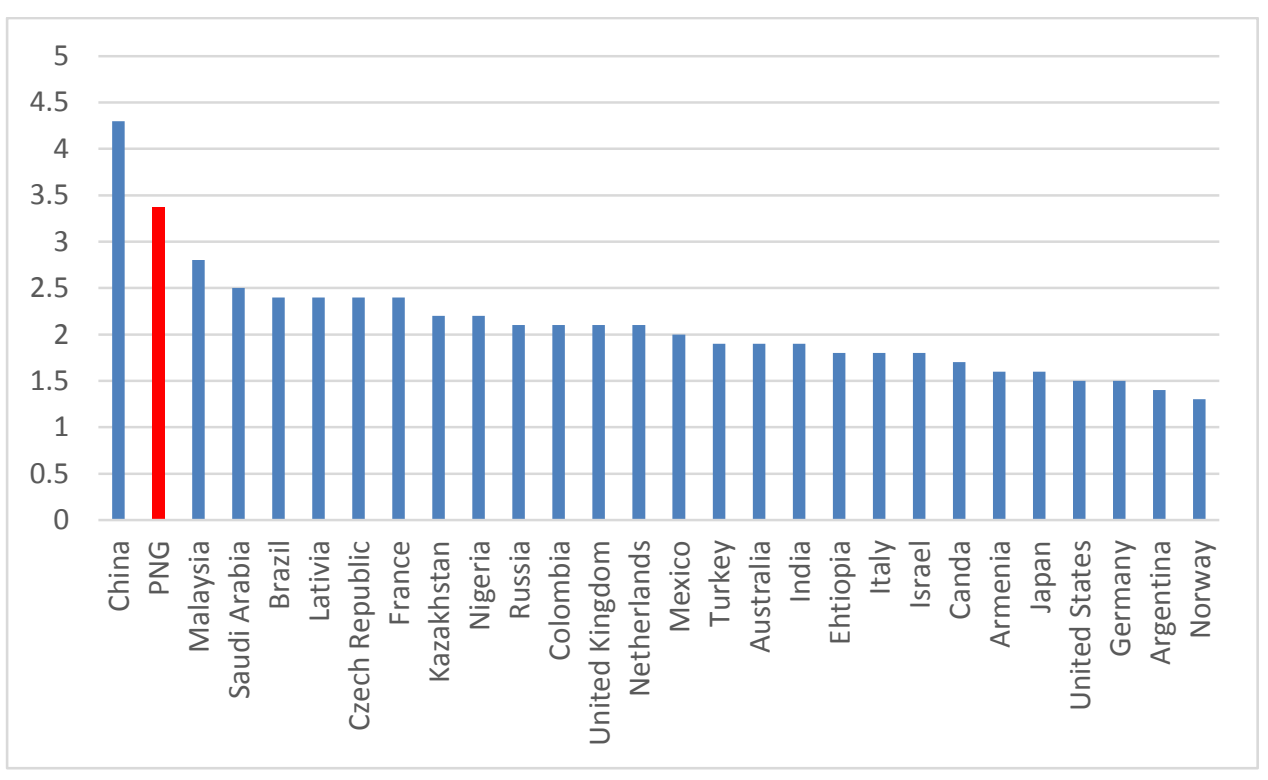

Sources: PNG data from this paper. Other countries from Altbach et al. (2012).

\section{Conclusions}

Some simple but important conclusions can be drawn from this analysis. From an international perspective, academics are not underpaid. Indeed, academic salaries in PNG are generous compared to what is observed in other developing countries. Nevertheless, we can see why universities struggle to retain their senior staff in disciplines also in demand from the public sector, such as economics and accounting. PNG universities will also struggle to keep their junior staff in such disciplines from taking up jobs in SOEs or statutory authorities. Junior academics are unlikely to head to the public service (at least not for financial reasons) but they will find SOE salaries attractive. There will also be some statutory authorities which offer salaries above our sample SA. If so, then university salaries are not competitive against SOEs and a range of statutory authorities.

These results explain what we can observe in the university sector. In particular, the UPNG School of Business and Administration has found it difficult to attract and retain staff. What can be done?

First, there is clearly scope for an increase in salaries, but, since academic salaries are already high by international standards, any increase should not be across the board. Rather, it should be carefully targeted to those disciplines where there is competition from the market.

Second, staff are already permitted to undertake consultancies, and this policy should remain in place. However, too much reliance on consultancy income will undermine teaching and research performance. 
Third, allowances are very important for university remuneration: much more important than for any other public sector institution. Where universities are able to provide housing, they should take measures to improve their housing stock, in terms of both quantity and quality.

Fourth, it will be difficult, and perhaps impossible and indeed undesirable, to close the gap between academic and SOE salaries. Other measures, such as improving the job satisfaction of academics by improving the work environment, and increasing the supply of quality candidates to fill academic positions will also be critical for ensuring the future of disciplines such as commerce and economics in Papua New Guinea.

Finally, and on a somewhat different topic, the fact that the ratio of PNG salaries to GDP per capita is so high, and the highest for a sample of 29 countries (Figure 11) suggests just how dualistic the PNG economy is. This would be an interesting subject for further analysis.

\section{Reference}

Altbach, P.G, Resiberg, L., Yudkevich, M., Androushchak, G and Pacheco, I.F., 2012. Paying the Professoriate: a global comparison of compensation and contracts, Routledge, New York. 